\title{
PROFIL KARAKTER PROKRASTINASI AKADEMIK PADA SISWA SMP DALAM PEMBELAJARAN MATEMATIKA
}

\author{
Dian Evelina Sahaya Ami ${ }^{1}$, Tri Nova Hasti Yunianta ${ }^{2}$ \\ ${ }^{1,2}$ Universitas Kristen Satya Wacana, Jalan Diponegoro No.52-60 Salatiga \\ sahayaami@gmail.com
}

\begin{abstract}
Academic Procrastination is defined as an action of students who intentionally delay their assignments and prefer doing things that attract them more. Some students at Junior High School 7, Salatiga stated that mathematics is a difficult lesson therefore it led them being reluctant in doing the assignments given by the teachers. This study discusses the academic procrastination of junior high school students, the factors that cause students delaying to work on assignments, and the impacts of academic procrastination on mathematics learning. This study used qualitative and quantitative (mix method) and used purposive sampling technique. This research sample are 30 students at Junior High School in Salatiga who take Intra School Student Organization (OSIS). Data retrieval is conducted by students filling out questionnaires and followed by interview the students who fit the criteria. The criteria is derived by looking at the result of the values that have been processed through a questionnaire. The instrument in this study is the researcher and the supporting instrument is the academic procrastination questionnaires. The result found that the gender of the students indicated a relationship to academic procrastination whereas age does not play a significant role in this condition. Joining OSIS is one of factors that causes students' procrastination. The impacts of procrastination are students tend to be disrupted in learning mathematics, getting accumulated assignments, not being able to do math assignments and do not understand the material taught by the teacher.
\end{abstract}

Keywords: Academic Procrastination, Junior High School Students, Mathematics, OSIS.

\begin{abstract}
Abstrak
Prokrastinasi akademik adalah sebuah tindakan seorang pelajar yang suka menunda-nunda pekerjaannya dan lebih memilih melakukan hal-hal yang lebih menarik baginya. Beberapa siswa di Sekolah Menengah Pertama (SMP) Negeri 7 Salatiga menyatakan bahwa matematika mata pelajaran yang sulit sehingga membuat siswa kurang tertarik mengerjakan tugas-tugas yang diberikan. Penelitian ini bertujuan untuk mendeskripsikan tentang perilaku prokrastinasi akademik siswa SMP, mencari faktor-faktor yang menyebabkan siswa menundanunda mengerjakan tugas, dan dampak dari melakukan prokrastinasi akademik terhadap pembelajaran matematika. Penelitian ini merupakan jenis penelitian mix method (metode campuran) yaitu kuantitatif dan kualitatif. Teknik pengambilan sampel dengan teknik purposive sampling. Sampel penelitian adalah 30 siswasiswi SMP yang mengikuti Organisasi Siswa Intra Sekolah (OSIS). Pengambilan data dilakukan dengan siswa mengisi lembar kuesioner dan dilanjutkan dengan wawancara terhadap siswa yang memenuhi kriteria, yaitu dengan melihat hasil nilai yang telah diolah melalui lembar kuesioner. Instrumen dalam penelitian ini adalah diri sendiri. Instrumen pendukung yaitu kuesioner prokrastinasi akademik. Hasil penelitian mendapatkan bahwa jenis kelamin mengindikasikan ada kaitan pada karakter prokrastinasi akademik siswa dan usia tidak. Adapun alasan mengikuti OSIS bukan menjadi salah satu faktor siswa melakukan prokrastinasi. Dampak dari prokrastinasi yaitu siswa terganggu dalam belajar matematika, tugas menumpuk, tidak bisa mengerjakan tugas matematika dan tidak paham materi yang diajarkan oleh guru.
\end{abstract}

Kata Kunci: Osis, Pembelajaran Matematika, Prokrastinasi Akademik, Siswa SMP

\section{PENDAHULUAN}

Prokrastinasi merupakan kebiasaan atau tindakan dalam menunda tugas sampai hari lain yang disebabkan oleh seorang yang tidak dapat membagi waktunya dengan tepat menurut proporsi yang sesuai dengan prioritas dan kepentingannya (Salsabiela et al., 2018). Ilyas (2017) mengatakan bahwa banyak orang yang mengartikan prokrastinasi disebabkan oleh menunda pekerjaan tugas, dan orang melakukan tugas itu karena tidak suka pada tugas yang sudah diberikan, maka dari itu mereka lebih memilih untuk menghindarinya.

Suasana atau kondisi lingkungan yang tepat untuk melakukan prokrastinasi ketika lingkungan memiliki tingkat pengawasan yang rendah dalam lingkungan rumah maupun sekolah (Zakiyah et al., 2010). Salah satu faktor terjadinya prokrastinasi akademik menurut (Fauziah, 2015) adalah kesibukan 
Profil Karakter Prokrastinasi Akademik Pada Siswa SMP Dalam Pembelajaran Matematika, Dian Evelina Sahaya Ami,

di luar sekolah seperti berorganisasi, acara dengan keluarga, sudah memiliki pekerjaan, dan memilih untuk mengerjakannya nanti di rumah.

Hal yang menyebabkan seorang siswa takut terhadap pembelajaran matematika karena matematika selalu menekankan untuk menghafal rumus, menekankan kecepatan dalam penyelesaian, pengerjaan tugas dengan mandiri, dan seorang guru matematika terkesan otoriter (Nuraeni, 2013). Faktor-faktor yang menyebabkan seorang siswa takut terhadap matematika tersebut mengakibatkan siswa memilih untuk tidak mengerjakan tugas tersebut.

Terdapat aspek prokrastinasi akademik yang mempengaruhi siswa. Aspek prokrastinasi akademik menurut Mustakim (2015) yaitu: (1) perceived time, seorang yang gagal menepati janji jadwal pengumpulan tugas, lebih memikirkan saat ini dari pada waktu-waktu selanjutnya dan biasanya memiliki perilaku malas; (2) intention-action, hubungan antara keinginan dan tindakan yang digambarkan dengan seorang siswa yang memiliki keinginan untuk mengerjakan namun tidak memiliki waktu; (3) emotional distress, menimbulkan perasaan cemas karena belum mengerjakan tugasnya dengan jangka waktu yang hampir habis; (4) perceived ability, merasa percaya terhadap diri sendiri bahwa dia mampu menyelesaikannya sendiri, diikuti dengan perasaan gelisah, takut, menyalahkan diri sendiri.

Ciri-ciri prokrastinasi menurut Ferrari, Jhonson, \& McCown (1995) yang dimiliki oleh seorang prokrastinator yaitu: (1) penundaan dalam memulai dan menyelesaikan tugas; (2) keterlambatan dalam mengerjakan tugas; (3) kesenjangan waktu antara rencana dan kinerja aktual; (4) melakukan aktivitas yang lebih menyenangkan. Matematika merupakan mata pelajaran yang sering kali menjadi momok bagi siswa-siswi, karena siswa susah untuk dipahami, siswa susah untuk menghafal rumus-rumus matematika. Matematika membantu seorang siswa untuk berpikir kritis dan logis (Danoebroto, 2012) dari tugas yang diberikan guru. Penelitian yang relevan dari Yuniarti, Setyowani, \& Ninik (2018) penelitian yang akan dibuat ini menunjukan tentang minat dan efikasi diri pada prokrastinasi akademik.

Berdasarkan latar belakang permasalahan di atas, penelitian bertujuan untuk mencari tahu tentang profil karakter prokrastinasi akademik pada siswa SMP. Profil ini dilihat dari perbedaan jenis kelamin dan usia, faktor-faktor yang menyebabkan siswa menunda mengerjakan tugas dalam pembelajaran matematika, serta dampak apa saja yang terjadi ketika siswa memilih untuk melakukan prokrastinasi akademik terhadap pembelajaran matematika. Penelitian ini bermanfaat untuk menambah kajian lebih dalam tentang siswa SMP dan memberitahukan profil karakter prokrastinasi akademik kepada semua guru pada umumnya dan khususnya guru matematika agar pembelajaran yang diberikan lebih baik lagi.

\section{METODE}

Penelitian ini merupakan jenis penelitian mix method (metode campuran) yaitu kuantitatif dan kualitatif, ditunjukan dengan peneliti melakukan pengambilan data dengan menyebar kuesioner pada 
30 siswa yang mengikuti OSIS, setelah diolah kemudian diambil 3 siswa yang memiliki tingkat prokrastinasi paling tingi untuk melakukan wawancara. Teknik pengambilan sampel menggunakan teknik purposive, dimana teknik ini menggunakan cara dipilih dengan pertimbangan dan tujuan tertentu (Sugiyono, 2008). Instrumen dalam penelitian ini adalah diri sendiri dan instrumen pendukung yaitu kuesioner prokrastinasi akademik. Pengambilan data dilakukan dengan cara memberikan kuesioner pada siswa SMP yang mengikuti kegiatan OSIS di sekolah, dengan jumlah sampel adalah 30 siswa lalu melakukan wawancara pada tiga siswa yang memenuhi kriteria wawancara, yaitu nilai data kuesioner prokrastinasi akademik yang rendah.

Ada tiga tahap penelitian yang akan dilakukan, yang pertama adalah tahap perencanaan penelitian, yang dimulai dengan meminta izin ke sekolah yang akan mejadi tempat penelitian, untuk penyebaran kuesioner hingga melakukan kegiatan wawancara. Tahap yang kedua adalah tahap pelaksanaan penelitian (pengambilan data), dan yang terakhir adalah tahap analisis data penelitian dengan melakukan analisis atau mengolah data yang telah didapatkan dari tahap sebelumnya. Pengumpulan data menggunakan empat metode (Creswell, 2015) yaitu: (1) pengamatan, untuk mengumpulkan catatan atau melakukan pengamatan lapangan merupakan tugas utama dari metode pengamatan; (2) non-tes, dilakukan untuk menggali informasi dalam menentukan pola pikir seorang siswa terhadap karakter prokrastinasi. Bentuk non-tes yang dilakukan adalah dengan pemberian kuesioner; (3) wawancara, untuk mendapatkan hasil yang lebih rinci. Wawancara dilakukan bertemu secara langsung; (4) dokumentasi, sebagai catatan peristiwa yang sudah berlalu berbentuk: tulisan, gambar.

Instrumen observasi umum digunakan dalam mengobservasi aktivitas dalam proses pembelajaran siswa, antara lain: check list, anecdotal record dan rating scale (Perdata, 2016) dan tahap yang harus dilakukan adalah melakukan non-tes pada partisipan, lalu melakukan wawancara disertai dengan dokumentasi. Analisis data kuantitatif hasil penelitian menggunakan analisis persentase. Analisis data kualitatif dilakukan dengan 4 langkah, yaitu: (1) menelaah; (2) mereduksi data; (3) menyusun berdasarkan kategorinya; (4) memeriksa keabsahan data. Keabsahan data/validasi dan reliabilitas melalui empat penilaian yang dilakukan (Sugiyono, 2008) yaitu: (1) kredibilitas, suatu hasil dalam penelitian dapat dikatakan memiliki kredibilitas yang tinggi dilihat dari tingkat keberhasilan dan tercapainya tujuan mengeksplore masalahnya (Afiyanti, 2008); (2) transferabilitas, transferabilitas merupakan istilah yang menggantikan konsep generalisasi data (Afiyanti, 2008); (3) dependabilitas, dependabilitas dilakukan dengan cara mengaudit terhadap seluruh proses penelitian (Sugiyono, 2008); (4) konfirmabilitas, konfirmabilitas merupakan hasil penelitian yang berkaitan dengan proses yang dilakukan sehingga dapat memenuhi data confirmability, jangan sampai proses tidak ada, namun hasil ada. Kredibilitas data dalam penelitian ini dijamin dengan menggunakan triangulasi metode. 
Profil Karakter Prokrastinasi Akademik Pada Siswa SMP Dalam Pembelajaran Matematika, Dian Evelina Sahaya Ami,

\section{HASIL}

Karakteristik partisipan dalam penelitian ini meliputi jenis kelamin dan usia dari 30 siswa yang menjadi sampel penelitian. Data sampel yang mengikuti organisasi di sekolah berjenis kelamin perempuan dengan jumlah 22 orang dan laki-laki sebanyak 8 orang. Ada 5 tingkatan usia partisipan, mulai usia 12 tahun sampai dengan 16 tahun. Mayoritas partisipan berusia 14 tahun dengan 16 partisipan, urutan terakhir dengan usia 12 tahun adalah satu orang.

Kuesioner berisi 22 pernyataan dengan masing-masing indikator tersebut skala diberikan berupa pertanyaan-pertanyaan yang disertai altenatif jawaban sangat setuju (SS), setuju (S), raguragu (R), kurang setuju (KS), dan tidak setuju (TS). Model skoring untuk alternatif jawaban untuk favorabel adalah sangat setuju berskor 5 dan tidak setuju bernilai 1, sedangkan untuk skor sangat setuju bagian unfavorabel adalah 1 dan untuk tidak setuju adalah 5 dengan skala seperti pada Tabel 1 lalu dilanjutkan dengan melakukan wawancara pada siswa yang dipilih sesuai kriteria.

\section{Tabel 1.}

Sebaran item

\begin{tabular}{|c|c|c|c|}
\hline Sub Aspek & Favorabel & Unfavorabel & Total \\
\hline Menunda-nunda & 1,2 & $3,4,5$ & 5 \\
\hline Keterlambatan & $6,7,8$ & $9,10,11$ & 6 \\
\hline Kesenjangan Waktu & 12,13 & $14,15,16$ & 5 \\
\hline Melakukan Aktivitas Lain & $17,18,19$, & $20,21,22$ & 6 \\
\hline
\end{tabular}

Karakteristik responden yang diteliti memiliki beberapa perbedaan meliputi gender dan usia. Rangkuman krakteristik responden dapat dilihat pada Tabel 2.

\section{Tabel 2.}

Karakteristik Responden

\begin{tabular}{|c|c|c|}
\hline Karakteristik & Jumlah (orang) & Persentase (\%) \\
\hline Jenis kelamin & & \\
\hline 1. Perempuan & 22 & $73,3 \%$ \\
\hline 2. Laki-laki & 8 & $26,7 \%$ \\
\hline Usia & & \\
\hline 1. 12 tahun & 1 & $3,3 \%$ \\
\hline 2. 13 tahun & 4 & $13,3 \%$ \\
\hline 3. 14 tahun & 16 & $53,3 \%$ \\
\hline 4. 15 tahun & 7 & $23,3 \%$ \\
\hline 5. 16 tahun & 2 & $6,7 \%$ \\
\hline
\end{tabular}

Hasil data angket/kuesioner tertutup dari 30 subjek yang diteliti dapat dilihat pada Tabel 3. Dari data tersebut 18 siswa dari 30 siswa atau sekitar 60\% siswa SMP yang aktif berorganiasi cenderung prokrastinasi ketika pembelajaran matematika. Adapun penjelasan lebih lanjut mengenai gender dan usia akan dibahas lebih lanjut. 


\section{Tabel 3.}

Rekap Data Hasil Penelitian

\begin{tabular}{|c|c|c|c|c|c|c|c|c|c|c|c|c|c|c|c|c|c|c|c|c|c|c|c|c|c|c|c|}
\hline \multirow{2}{*}{ RESPONDEN } & \multirow{2}{*}{ USIA } & \multirow{2}{*}{$\begin{array}{c}\text { JENIS } \\
\text { KELAMIN }\end{array}$} & \multicolumn{22}{|c|}{ PERNYATAAN } & \multirow{2}{*}{$\begin{array}{l}\text { SKOR } \\
\text { TOTAL }\end{array}$} & \multirow{2}{*}{ PERSENTASE } & \multirow{2}{*}{ KETERANGAN } \\
\hline & & & 1 & 2 & 3 & 4 & 5 & 6 & 7 & 8 & 9 & 10 & 11 & 12 & & 14 & 15 & 16 & 17 & 18 & 19 & 20 & 21 & 22 & & & \\
\hline 1 & 12 & Laki-laki & 2 & 3 & 5 & 5 & 1 & 5 & 2 & 4 & 3 & 5 & 4 & 1 & 2 & 4 & 5 & 5 & 5 & 5 & 5 & 4 & 5 & 4 & 84 & 76 & Prokrastinasi \\
\hline 2 & 13 & Laki-laki & 2 & 5 & 1 & 2 & 1 & 5 & 1 & 4 & 5 & 5 & 4 & 1 & 2 & 4 & 2 & 5 & 3 & 3 & 2 & 3 & 4 & 5 & 69 & 63 & Prokrastinasi \\
\hline 3 & 13 & Laki-laki & 2 & 4 & 2 & 2 & 3 & 4 & 3 & 2 & 3 & 4 & 4 & 2 & 3 & 4 & 4 & 4 & 2 & 3 & 3 & 2 & 3 & 4 & 67 & 61 & Prokrastinasi \\
\hline 4 & 13 & Laki-laki & 3 & 4 & 1 & 3 & 3 & 5 & 2 & 2 & 3 & 3 & 4 & 2 & 3 & 3 & 5 & 5 & 3 & 3 & 4 & 2 & 3 & 4 & 70 & 64 & Prokrastinasi \\
\hline 5 & 13 & Laki-laki & 2 & 2 & 4 & 3 & 2 & 5 & 2 & 2 & 1 & 3 & 3 & 2 & 2 & 4 & 3 & 5 & 4 & 5 & 3 & 5 & 4 & 2 & 68 & 62 & Prokrastinasi \\
\hline 6 & 14 & Laki-laki & 4 & 4 & 1 & 1 & 5 & 1 & 1 & 5 & 4 & 2 & 4 & 1 & 3 & 2 & 2 & 2 & 2 & 3 & 1 & 2 & 2 & 3 & 55 & 50 & Netral \\
\hline 7 & 14 & Laki-laki & 1 & 4 & 5 & 5 & 1 & 1 & 3 & 2 & 3 & 4 & 4 & 2 & 4 & 4 & 5 & 5 & 5 & 4 & 3 & 4 & 4 & 5 & 78 & 71 & Prokrastinasi \\
\hline 8 & 14 & Laki-laki & 1 & 5 & 5 & 5 & 2 & 4 & 4 & 5 & 4 & 4 & 3 & 1 & 5 & 4 & 4 & 5 & 2 & 3 & 4 & 5 & 5 & 2 & 82 & 75 & Prokrastinasi \\
\hline 9 & 14 & Perempuan & 3 & 4 & 3 & 3 & 2 & 4 & 2 & 3 & 3 & 2 & 3 & 4 & 3 & 4 & 4 & 4 & 4 & 3 & 3 & 2 & 4 & 3 & 70 & 64 & Prokrastinasi \\
\hline 10 & 14 & Perempuan & 3 & 4 & 3 & 2 & 2 & 3 & 3 & 4 & 3 & 2 & 4 & 3 & 3 & 2 & 3 & 3 & 2 & 3 & 3 & 2 & 2 & 4 & 63 & 57 & Netral \\
\hline 11 & 14 & Perempuan & 2 & 5 & 3 & 1 & 5 & 3 & 1 & 1 & 4 & 2 & 5 & 5 & 2 & 3 & 2 & 5 & 3 & 4 & 3 & 4 & 1 & 2 & 66 & 60 & Vetral \\
\hline 12 & 14 & Perempuan & 2 & 5 & 2 & 4 & 4 & 5 & 1 & 2 & 2 & 2 & 4 & 5 & 4 & 3 & 3 & 4 & 2 & 4 & 1 & 3 & 1 & 4 & 67 & 61 & Prokrastinasi \\
\hline 13 & 14 & Perempuan & 4 & 3 & 1 & 4 & 1 & 4 & 1 & 3 & 5 & 5 & 5 & 5 & 5 & 4 & 4 & 5 & 4 & 4 & 1 & 5 & 1 & 5 & 79 & 72 & Prokrastinasi \\
\hline 14 & 14 & Perempuan & 3 & 4 & 2 & 3 & 1 & 3 & 2 & 2 & 2 & 1 & 3 & 3 & 3 & 4 & 4 & 5 & 4 & 4 & 2 & 3 & 2 & 4 & 64 & 58 & Netral \\
\hline 15 & 14 & Perempuan & 1 & 2 & 4 & 4 & 4 & 5 & 2 & 2 & 4 & 4 & 4 & 5 & 5 & 4 & 4 & 4 & 5 & 4 & 4 & 4 & 4 & 4 & 83 & 75 & Prokrastinasi \\
\hline 16 & 14 & Perempuan & 3 & 4 & 2 & 2 & 2 & 2 & 1 & 4 & 1 & 1 & 2 & 2 & 5 & 2 & 3 & 2 & 3 & 4 & 1 & 2 & 1 & 3 & 52 & 47 & Netral \\
\hline 17 & 14 & Perempuan & 4 & 5 & 4 & 3 & 3 & 5 & 3 & 4 & 4 & 1 & 4 & 2 & 4 & 2 & 5 & 5 & 4 & 4 & 4 & 4 & 4 & 4 & 82 & 75 & Prokrastinasi \\
\hline 18 & 14 & Perempuan & 2 & 5 & 1 & 2 & 3 & 4 & 2 & 3 & 1 & 3 & 5 & 3 & 4 & 3 & 4 & 5 & 3 & 3 & 1 & 3 & $2 \mid$ & 4 & 66 & 60 & Netral \\
\hline 19 & 14 & Perempuan & 2 & 3 & 2 & 2 & 2 & 4 & 3 & 3 & 3 & 3 & 3 & 3 & 3 & 3 & 3 & 4 & 5 & 5 & 3 & 3 & 3 & 5 & 70 & 64 & Prokrastinasi \\
\hline 20 & 14 & Perempuan & 1 & 3 & 4 & 3 & 1 & 4 & 1 & 2 & 3 & 4 & 3 & 1 & 2 & 4 & 4 & 5 & 3 & 2 & 2 & 3 & 2 & 5 & 62 & 56 & Netral \\
\hline 21 & 14 & Perempuan & 2 & 4 & 3 & 2 & 1 & 5 & 1 & 2 & 1 & 3 & 4 & 2 & 4 & 3 & 4 & 3 & 2 & 4 & 1 & 2 & 1 & 4 & 58 & 53 & Netral \\
\hline 22 & 15 & Perempuan & 1 & 2 & 3 & 2 & 1 & 5 & 1 & 3 & 2 & 3 & 4 & 2 & 3 & 2 & 3 & 3 & 4 & 2 & 1 & 3 & 1 & 5 & 56 & 51 & Netral \\
\hline 23 & 15 & Perempuan & 1 & 4 & 3 & 4 & 2 & 5 & 2 & 2 & 3 & 4 & 4 & 2 & 2 & 3 & 2 & 4 & 2 & 2 & 2 & 4 & 1 & 4 & 62 & 56 & Netral \\
\hline 24 & 15 & Perempuan & 2 & 2 & 3 & 4 & 3 & 3 & 2 & 3 & 3 & 3 & 3 & 2 & 3 & 3 & 4 & 3 & 3 & 3 & 3 & 3 & 3 & 3 & 64 & 58 & Netral \\
\hline 25 & 15 & Perempuan & 2 & 5 & 2 & 4 & 1 & 4 & 2 & 2 & 2 & 3 & 4 & 2 & 4 & 2 & 5 & 4 & 5 & 5 & 2 & 3 & 3 & 4 & 70 & 64 & Prokrastinasi \\
\hline 26 & 15 & Perempuan & 2 & 2 & 3 & 3 & 2 & 5 & 2 & 2 & 4 & 1 & 2 & 5 & 5 & 3 & 5 & 5 & 5 & 4 & 2 & 3 & 4 & 5 & 74 & 67 & Prokrastinasi \\
\hline 27 & 15 & Perempuan & 2 & 4 & 2 & 3 & 2 & 3 & 2 & 3 & 2 & 3 & 3 & 2 & 3 & 3 & 3 & 4 & 2 & 4 & 3 & 3 & 3 & 4 & 63 & 57 & Netral \\
\hline 28 & 15 & \begin{tabular}{|l} 
Perempuan \\
\end{tabular} & 2 & 2 & 4 & 2 & 2 & 5 & 2 & 3 & 2 & 2 & 4 & 4 & 4 & 4 & 5 & 5 & 4 & 5 & 2 & 4 & 4 & 5 & 76 & 69 & Prokrastinasi \\
\hline 29 & 16 & Perempuan & 2 & 4 & 3 & 4 & 2 & 3 & 1 & 4 & 2 & 3 & 3 & 3 & 3 & 3 & 5 & 2 & 2 & 4 & 3 & 4 & 4 & 5 & 69 & 63 & Prokrastinasi \\
\hline 30 & 16 & Perempuan & 1 & 5 & 3 & 4 & 1 & 5 & 1 & 1 & 4 & 5 & 4 & 3 & 4 & 5 & 5 & 5 & 5 & 5 & 5 & 5 & 5 & 5 & 86 & 78 & Prokrastinasi \\
\hline
\end{tabular}

\section{Ditinjau dari Gender}

Data pada Tabel 4 menyatakan karakter prokrastinasi akademik yang ditinjau dari gender siswa. Data ini memberikan gambaran perbandingan antara siswa laki-laki lebih dan perempuan dalam kecenderungan memiliki karakter prokrastinasi akademik.

Tabel 4.

Prokrastinasi Akademik Ditinjau dari Jenis Kelamin

\begin{tabular}{|l|l|c|c|c|}
\hline $\begin{array}{c}\text { Jenis } \\
\text { Kelamin }\end{array}$ & Jumlah & $\begin{array}{c}\text { Persentase } \\
\text { Prokrastinasi }\end{array}$ & Keterangan & Kesimpulan \\
\hline Laki-laki & 8 & $87,5 \%$ & $\begin{array}{c}7 \text { dari } 8 \text { siswa cenderung } \\
\text { berkarakter prokrastinasi }\end{array}$ & $\begin{array}{c}\text { Secara umum } \\
\text { cenderung } \\
\text { Prokrastinasi }\end{array}$ \\
\hline Perempuan & 22 & $50 \%$ & $\begin{array}{c}11 \text { dari } 22 \text { siswi } \\
\text { cenderung berkarakter } \\
\text { prokrastinasi }\end{array}$ & $\begin{array}{c}\text { Secara umum } \\
\text { cenderung } \\
\text { seimbang } \\
\text { proporsinya }\end{array}$ \\
\hline
\end{tabular}

Gender atau jenis kelamin merupakan suatu bentuk tingkah laku, karakteristik, atribute dan jenis kelamin adalah konsep pembeda antara pria dan wanita tidak hanya dari biologis namun juga dari psikologi (Handaru et al., 2014). Dilihat dari Tabel 3 menyatakan bahwa dari 8 siswa laki-laki, ada 7 siswa yang berkarakter prokrastinasi akademik, sedangkan dari 22 siswa perempuan, terdapat 11 siswa yang berkarakter prokrastinasi. Karakter prokrastinasi akademik siswa-siswi yang mengikuti OSIS dapat terlihat dari persentase bahwa ini menyatakan lebih cenderung sangat tidak prokrastinasi, 
Profil Karakter Prokrastinasi Akademik Pada Siswa SMP Dalam Pembelajaran Matematika, Dian Evelina Sahaya Ami,

tidak prokrastinasi, netral, prokrastinasi atau sangat prokrastinasi. Hasil ini diperkuat dengan penelitian Tiruwork (2014), menunjukkan bahwa siswa di Ethiopia yang berjenis kelamin laki-laki memiliki tingkat prokrastinasi lebih tinggi.

\section{Ditinjau dari Usia}

Mengacu pada data yang sudah diperoleh melalui penyebaran kuesioner, diperoleh bahwa seperti pada Tabel 5 diperlihatkan prokrastinasi siswa yang ditinjau dari usia. Terdapat lima tingkatan usia yang ada pada data penelitian dan tersebar berdistribusi normal berdasarkan banyak siswa dengan puncak di usia 14 tahun.

Tabel 5.

Prokrastinasi Ditinjau Dari Usia

\begin{tabular}{|c|c|c|c|c|c|}
\hline Usia & $\begin{array}{c}\text { Jumlah } \\
\text { Siswa }\end{array}$ & $\begin{array}{l}\text { Jumlah yang } \\
\text { Prokrastinasi }\end{array}$ & Presentase & Keterangan & Kesimpulan \\
\hline 12 & 1 & 1 & $100 \%$ & Prokrastinasi & Prokrastinasi \\
\hline \multirow{2}{*}{13} & \multirow{2}{*}{4} & 3 & $75 \%$ & Prokrastinasi & \multirow{2}{*}{$\begin{array}{l}\text { Cenderung } \\
\text { prokrastinasi }\end{array}$} \\
\hline & & 1 & $25 \%$ & Tidak prokrastinasi & \\
\hline \multirow{2}{*}{14} & \multirow{2}{*}{16} & 7 & $43,75 \%$ & Prokrastinasi & \multirow{2}{*}{$\begin{array}{l}\text { Cenderung tidak } \\
\text { prokrastinasi }\end{array}$} \\
\hline & & 9 & $56,25 \%$ & Tidak prokrastinasi & \\
\hline \multirow{2}{*}{15} & \multirow{2}{*}{7} & 5 & $71,43 \%$ & Prokrastinasi & \multirow{2}{*}{$\begin{array}{l}\text { Cenderung } \\
\text { prokrastinasi }\end{array}$} \\
\hline & & 2 & $28,57 \%$ & Tidak prokrastinasi & \\
\hline 16 & 2 & 2 & $100 \%$ & Prokrastinasi & Prokrastinasi \\
\hline
\end{tabular}

Anak dengan usia 14 tahun lebih cenderung tidak berkarakter prokrastinasi, ini juga dinyatakan bahwa pada usia tersebut remaja mencari-cari hal tentang dirinya dan bergantung pada pertemanan dengan sebayanya (Wulandari, 2014), sedangkan anak yang berusia 12 tahun lebih tertarik dengan kegiatan mengeksplorasi dan berkreasi (Martha, 2007). Masa remaja (13-17 tahun) ditinjau dari rentang kehidupan manusia merupakan masa peralihan dari masa kanak-kanak menuju ke dewasa, dimana tugas perkembangan pada masa remaja menuntut perubahan besar dalam sikap dan pola perilaku anak (Nafeesa, 2018).

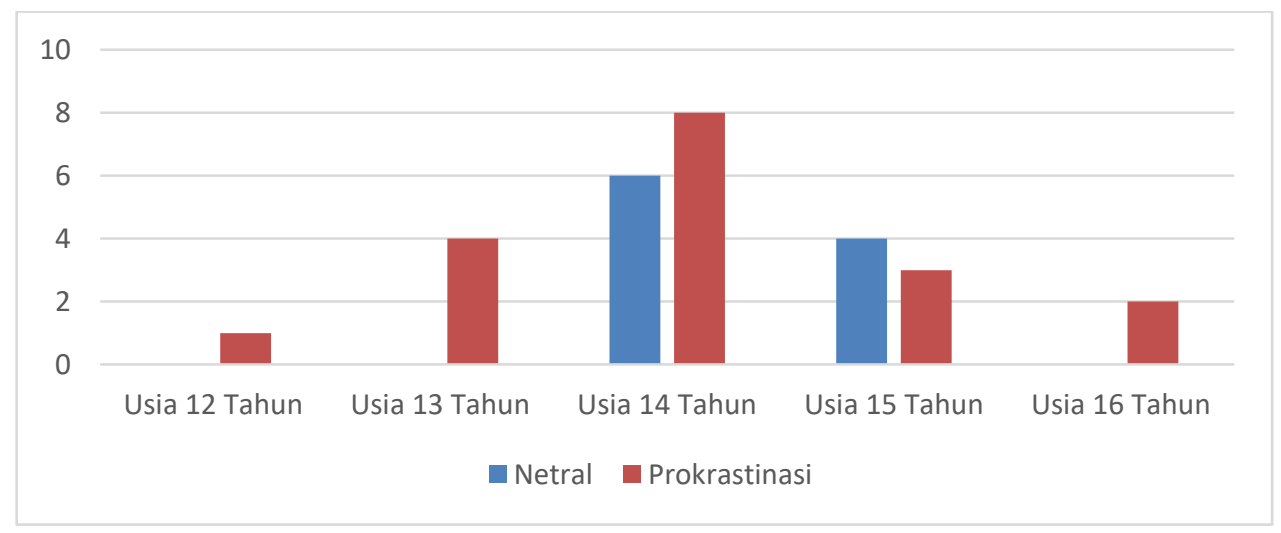

Diagram 1. Diagram Kecenderungan Siswa SMP yang Aktif dalam Organisasi Intra Sekolah 
Berdasarkan Diagram 1 ini diperoleh bahwa siswa yang aktif dalam Organisasi Intra Sekolah cenderung memiliki karakter prokrastinasi. Ditemukan fakta bahwa pada usia 14 dan 15 tahun ada siswa yang tidak cenderung memiliki karakter prokrastinasi.

\section{Faktor Penyebab Prokrastinasi Akademik}

Faktor penyebab prokrastinasi akademik diketahui melalui data setelah melakukan mewawancara pada siswa yang memiliki karakteristik prokrastinasi tinggi. Faktor penyebab prokrastinasi akademik dikelompokkan menjadi dua, yaitu faktor internal dan faktor eksternal. Faktor internal adalah faktor yang berasal dari diri sendiri dan yang mempengaruhi yaitu siswa memiliki sikap malas, lebih memilih mendengarkan lagu, tidak mengatur waktu dengan baik, memiliki rasa cemas berlebihan sehingga lebih cenderung menghindar, tidak takut dihukum sehingga memilih untuk menunda, materi yang disampaikan sulit dipahami oleh siswa, dan siswa lebih suka dengan pelajaran yang lainnya.

Rasa malas pada siswa sering datang dipicu dengan adanya hal yang lebih menarik perhatian siswa tersebut dan rasa malas tersebut timbul karena kurangnya motivasi sehingga sulit untuk untuk memulai dalam mengerjakan sesuatu (Fauziah, 2015). Menumbuhkan motivasi dalam diri seseorang juga ditentukan oleh waktu belajar yang baik dan tepat. Banyak penyebab mengapa siswa memiliki masalah akademis, salah satunya adalah siswa tidak tepat dalam menentukan waktu belajar dirinya sendiri (Juliasari \& Kusmanto, 2016). Minat siswa terhadap mata pelajaran matematika juga mempengaruhi prokrastinasi akademik siswa. Saat guru mengajar dan siswa tidak mengerti dengan apa yang disampaikan, sehingga siswa tersebut tidak memahami pelajaran matematika dan tidak dapat menyelesaikan tugas yang diberikan dengan baik. Mengerjakan tugas matematika adalah karena siswa tidak suka dengan pelajaran matematika karena menakutkan, penuh dengan angka dan rumus (Leonard \& Supardi, 2010)

Kelompok yang kedua adalah faktor eksternal berarti faktor yang dipengaruhi dari luar individu itu sendiri dan yang mempengaruhi adalah tertarik dengan hal-hal di luar tugas seperti bermain smartphone, bermain dengan teman-teman, mengandalkan/mencontoh hasil pekerjaan teman dalam mengerjakan tugas.

Seperti penjelasan pada faktor internal, siswa lebih memilih melakukan hal-hal yang menyenangkan dibanding mengerjakan tugas yang diberikan guru padanya. Beberapa contoh dari hal menyenangkan yang dikerjakan oleh partisipan adalah bermain smartphone dan bermain bersama teman sebayanya, seperti yang disampaikan oleh salah satu partisipan:

“...Sering seperti itu, hendak belajar dan mengerjakan matematika tetapi sudah membuat jadwal jam sekian untuk belajar matematika, mengerjakan matematika tetapi kalau sudah memegang smartphone pasti langsung lupa, langsung malas untuk mengerjakan..."

Menurut Yaningsih (2018), teman sebaya dapat mempengaruhi prokrastinasi siswa, ditunjukan dengan siswa yang terbiasa dengan menunggu temannya dalam mengerjakan tugas 
Profil Karakter Prokrastinasi Akademik Pada Siswa SMP Dalam Pembelajaran Matematika, Dian Evelina Sahaya Ami,

matematika yang diberikan oleh guru. Siswa yang hanya mengandalkan teman dalam mengerjakan tugas biasanya tidak tahu proses dari cara menyelesaikan tugas tersebut.

\section{Dampak Prokrastinasi akademik}

Ada beberapa dampak yang ditemukan oleh seorang siswa yang memiliki karakter prokrastinasi setelah melakukan wawancara, berikut beberapa dampak yang sudah dianalis: 1) saat siswa lebih memilih melakukan hal yang menyenangkan seperti bermain smartphone, bermain bersama teman menyebabkan siswa terganggu dalam belajar matematika; 2) tugas-tugas semakin menumpuk saat siswa hanya bermalas-malasan; 3) jalan keluar instan hanya bisa menyontek dan mengandalkan teman sehingga tidak tahu cara mengerjakan tugas matematika tersebut; 4) tidak paham materi yang diajarkan oleh guru.

Menurut Chusna (2017) dampak dari seorang anak yang terlalu banyak bermain smartphone adalah anak tersebut akan lebih emosional dan tidak mau diganggu saat asik bermain game, itu sebabnya anak lebih akan habiskan waktunya untuk bermain smartphone, sehingga anak tidak mengerjakan tugas yang diberikan oleh guru. Sama halnya dengan anak yang memilih berkumpul dengan temantemannya dari pada belajar ataupun mengerjakan tugas matematika, karena menurut Saefudin \& Nurizzati (2018) menyebutkan bahwa pada usia remaja (12-15 tahun) teman sebaya merupakan kebutuhan yang sangat penting, dilihat dari menyatakan kesetiakawanannya.

\section{KESIMPULAN}

Berdasarkan hasil penelitian, pembahasan, temuan dalam penelitian yang sudah dilakukan terdapat bermacam-macam cara dalam menyelesaikan tugas matematikanya. Ada partisipan yang memiliki karakteristik cenderung prokrastinasi dan partisipan yang cenderung memiliki karakteristik netral. Seorang anak yang tidak berkarakter prokrastinasi akademik sebanyak 12 partisipan dari 30 partisipan. Ditinjau dari jenis kelamin dalam organisasi tersebut menyebutkan bahwa kecenderungan partisipan yang berkarakter prokrastinasi adalah laki-laki. Peneliti menemukan bahwa karakter prokrastinasi juga dapat ditinjau dari usia partisipan. Usia yang cenderung seimbang dalam memiliki karakter prokrastinasi dan netral adalah anak berusia 14 dan 15 tahun. Namun, tingkatan usia tidak menjadi patokan siswa berkarakter prokrastinasi akademik. Terdapat empat dampak dari prokrastinasi akademik. Hasil ini belum tentu menyatakan bahwa siswa yang aktif mengikuti organisasi di lingkungannya tidak selalu memiliki karakter prokrastinasi akademik. Memerlukan penelitian lebih lanjut untuk mendukung hasil penelitian ini atau mungkin bisa diperoleh hasil yang berbeda. Kemudian bagi siswa, memilih teman sebaya memiliki peran penting dalam menentukan karakter untuk masa yang akan datang, apakah dia berkarakter prokrastinasi atau tidak. 


\section{DAFTAR PUSTAKA}

Afiyanti, Y. (2008). Validitas dan reliabilitas dalam penelitian kualitatif. Jurnal Keperawatan Indonesia, 12(2), 137-141.

Chusna, P. A. (2017). Pengaruh media gadget pada perkembangan karakter anak. Dinamika Penelitian: Media Komunikasi Sosial Keagamaan, 17(2), 315-330. https://doi.org/10.21274/dinamika/2017.17.2.315-330

Danoebroto, S. W. (2012). Model pembelajaran matematika berbasis pendidikan multikultural. Jurnal Pembangunan Pendidikan: Fondasi Dan Aplikasi, 1(1), 94-107. https://doi.org/10.21831/jppfa.v1i1.1054

Fauziah, H. H. (2015). Fakor-faktor yang mempengaruhi prokrastinasi akademik pada mahasiswa fakultas psikologi Uin Sunan Gunung Djati Bandung. Psympathic: Jurnal Ilmiah Psikologi, 2(2), 123-132. https://doi.org/10.15575/psy.v2i2.453

Ferrari, J.R., Jhonson, J.L., \& McCown, W. G. (1995). Procrastination And Task Avoidance: Theory, Research and Treatment.

Handaru, A. W., Lase, E. P. S., \& Parimita, W. (2014). Analisis perbedaan tingkat prokrastinasi ditinjau dari gender, socio-personal, locus of control, serta kecerdasan emosional : studi pada mahasiswa program studi manajemen fE UNJ. Jurnal Riset Manajemen Sains Indonesia (JRMSI), 5(2), 243-263.

Ilyas, M. \& S. (2017). Perilaku prokrastinasi akademik siswa di SMA Islam Terpadu (IT) Boarding School Abu Bakar Yogyakarta. Jurnal Pemikiran Islam, 41(1), 71-82.

Juliasari, N., \& Kusmanto, B. (2016). Hubungan antara manajemen waktu belajar, motivasi belajar, dan fasilitas belajar dengan prestasi belajar matematika siswa SMP kelas VIII se-Kecamatan Danurejan Yogyakarta. UNION: Jurnal Ilmiah Pendidikan Matematika, 4(3), 405-412. https://doi.org/10.30738/.v4i3.435

Leonard \& Supardi, U. S. (2010). Pengaruh konsep diri, sikap siswa pada matematika, dan kecemasan siswa terhadap hasil belajar matematika. Cakrawala Pendidikan, 20(3), 259-262. https://doi.org/10.1007/s002669900030

Mustakim. (2015). Hubungan antara Locus Of Control Dengan Prokrastinasi Akademik Pada Siswa MAN 1 Medan.

Nafeesa. (2018). Faktor-faktor yang mempengaruhi prokrastinasi akademik siswa yang menjadi anggota organisasi siswa intra sekolah. Anthropos: Jurnal Antropologi Sosial Dan Budaya (Journal of Social and Cultural Anthropology), 4(1), 53-67. https://doi.org/10.24114/antro.v4i1.9884

Nuraeni, Z. (2013). Permainan anak untuk matematika. Prosiding Seminar Nasional Matematika Dan Pendidikan Matematika Dengan Tema "Penguatan Peran Matematika Dan Pendidikan Matematika Untuk Indonesia Yang Lebih Baik", November, 684-690. 
Profil Karakter Prokrastinasi Akademik Pada Siswa SMP Dalam Pembelajaran Matematika, Dian Evelina Sahaya Ami,

Perdata, I. B. K. (2016). Instrumen observasi kegiatan inti pembelajaran matematika berbasis pendekatan saintifik (5M) di SMA. Jurnal Santiaji Pendidikan, 6(2), 126-147.

Saefudin, A., \& Nurizzati, Y. (2018). Pengaruh gaya belajar siswa dan pergaulan teman sebaya terhadap prestasi belajar siswa pada mata pelajaran IPS kelas VIII di SMP Negeri 1 Mundu Kabupaten Cirebon. Edueksos: Jurnal Pendidikan Sosial \& Ekonomi, 7(1), 1-16. https://doi.org/10.24235/edueksos.v7i1.3110

Salsabiela, A.-, Atieq, B.-, Husna, A. A., Utami, A. N., Qurrotaa'yun, N. N., \& Qudsyi, H.-. (2018). TRASI (Training Motivasi) Untuk Menurunkan Prokrastinasi Akademik Siswa-Siswi MTs (Madrasah Tranawiyah). Persona:Jurnal Psikologi Indonesia, 7(2), 177-186. https://doi.org/10.30996/persona.v7i2.1501

Sugiyono. (2008). Metodologi penelitian pendidikan: pendekatan kuantitatif, kualitatif, dan $R \& D$.

Tiruwork, T. (2014). Academic procrastination and causal perception of tabor senior secondary students Ethiopia. Academic Procrastination \& Causal Perception of TSSS Ethiopia, 34-55.

Wulandari, A. (2014). Karakteristik pertumbuhan perkembangan remaja dan implikasinya terhadap masalah kesehatan dan keperawatannya. Jurnal Keperawatan Anak, 2(1), 39-43. https://jurnal.unimus.ac.id/index.php/JKA/article/view/3954

Yaningsih, S., \& Fachrurrozie. (2018). Self-regulated learning memoderasi pengaruh media sosial, ekstrakulikuler, dan teman sebaya terhadap prokrastinasi akademik. Economic Education Analysis Journal, 7(3), 909-923.

Yuniarti, S., Setyowani, N., \& Sunawan. (2018). Minat dan efikasi diri dengan prokrastinasi akademik pada mata pelajaran matematika. Indonesian Journal of Guidance and Counseling, 7(4), 31-38. http://journal.unnes.ac.id/sju/index.php/jbk

Zakiyah, N., Hidayati, F. N. R., \& Setyawan, I. (2010). Hubungan antara penyesuaian diri dengan prokrastinasi akademik siswa sekolah berasrama SMP N 3 Peterongan Jombang. Fakultas Psikologi Universitas Diponegoro, 8(2), 156-167. 